\title{
CHARACTERISTICS AND GENESIS OF MONTMORILONITIC CLAYSTONE FROM BANDUNG AREA, WONOSEGORO, BOYOLALI, CENTRAL JAVA, INDONESIA
}

\author{
Anita Yuliyanti, I Wayan Warmada, and Anastasia Dewi Titisari \\ Department of Geological Engineering, Gadjah Mada University, Yogyakarta, Indonesia
}

\begin{abstract}
The Bandung bentonite deposit is located in Wonosegoro District, Boyolali Regence, Central Java. Characteristics of bentonite in this area are very important due to increase demand on bentonite in the industry. Several methods are used to characterize the bentonite in this area, such as PLM (polarizing light microscope), X-Ray Diffraction and Scanning Electron Microscope combined with EDX measurements. The montmorilonitic claystone belongs to Kerek Formation from Banyuurip Member. This deposit consists of mainly montmorilonitic claystone interbedded with tuffaceous sandstone. Petrographical analysis shows that montmorilonitic claystone consists of mostly clay minerals with small amount of calcite, volcanic glass, feldspar, quartz, and opaque minerals. The clay minerals are likely as alteration product of volcanic glass. The oriented $X R D$ analyses show that the clay samples consist of Ca-montmorilonite, illite, and kaolinite. Physicochemical analyses of montmorilonitic claystone display that the initial CEC (cation exchange capacity) is 20 mgrek. $\mathrm{Na}_{2} \mathrm{O} / 200 \mathrm{gr}$ (54 mg. $\mathrm{Na}_{2} \mathrm{O} / 100 \mathrm{gr}$ ) and low swelling ability for about 2 times of its initial volume. Based on its mineralogical association, textures, and stratigraphic position, the montmorilonite is formed from devitivication of volcanic glass in a diagenetic environment with over $2 \mathrm{~km}$ thicks of overburden.
\end{abstract}

${ }^{*}$ Corresponding author: A. YULIYANTI, Department of Geological Engineering, Faculty of Engineering, Gadjah Mada University, Jl. Grafika 2 Yogyakarta, 55281, Indonesia. E-mail: warmada@gmail.com
Keywords: bentonite, montmorillonitic claystone, devitrivication, diagenesis, montmorillonite

\section{Introduction}

The preliminary studies (e.g. Arifin and Sudrajat, 1997; Utama, 2004; Suwasti, 2005; Titisari and Widiasmoro, 2006) revealed that natural bentonite is potentially contained in montmorillonitic claystone that is very abundant in Wonosegoro district. Montmorillonitic claystone can be found in some area including Bandung area. There is only a few literacy that explain detailly about the quality of montmorilonitic claystone in this area. This material had been mined in small scale and sold as ceramic and drilling mud raw materials, but now this activity has stoped. Eventhough, this material usage is not optimized yet. Therefore, the characterization and study about genesis of this material are very important as the first stage in optimizing the usage.

Clay had been defined as a sediment with grains less than 0,002 or $1 / 256 \mathrm{~mm}$ in diameter. It has plastic properties (natural plastic earth) and composed of hydrous aluminium silicate (Pettijohn, 1975). Montmorillonite had been proposed to define a kind of minerals from Montmorillon, France. It is hydrated aluminium silicate with silicate content 4 times of its aluminium, and also contain amount of alkali and earth alkali (Damour and Salvetat, 1847 vide Grim, 1968). Montmorillonite structure 
shows swelling characteristic of lattice mineral that become main characteristic of this group. Nowadays, this terminology has been used in minerals group as well as mineral. Some author has suggested different formula for montmorillonite. According to Grim (1968), the formula is $\left[(\mathrm{Mg}, \mathrm{Ca}) \cdot \mathrm{Al}_{2} \mathrm{O}_{3} \cdot 5 \mathrm{SiO}_{2} \cdot n \mathrm{H}_{2} \mathrm{O}\right]$. Montmorillonite has 2:1 layer type with dioctahedral $10 \AA$ structure and relatively low charge $(0.2-0.6)$, these structures give possibility for hidrates ions or polar ions to pass and absorbed in the interlayer space. It cause change in the average interlayer distance or called swelling (Grim, 1968; Millot, 1970; Velde, 1995). As clay minerals group, montmorillonite group is comprised of montmorillonite, beidellite and nontronite. Together with saponite group, it forms a bigger group called smectite (Grim, 1968).

Clay deposit that contain clay minerals from smectite group, esspecially montmorillonite as the predominant minerals is called bentonite (Grim, 1968). It can be divided into 2 type according to their mineralogical and physical properties. They are $\mathrm{Na}$ or $\mathrm{Na}-\mathrm{Ca}$ (intermediate) type which has high to medium swelling ability and calcium type which has low swelling ability (Takegi et al., 2005).

\section{Geology}

Based on Bemmelen (1949), the Bandung area is a west part of the Kendeng Anticlinorium. That zone is a fold-thrust belt that has margin to quaternary volcanic arc separated by Ngawi subzone alluvial. Geologically, the Bandung area is covered by rocks from Kerek Formation. This formation is characterized by intercalation of claystone, calcareous claystone, marl, calcareous tuffaceous sandstone and tuffaceous sandstone. Geology structures found in this area are folds (sincline and anticline) and reverse fault that have east - west orientation and also wrenching fault with north-east - south-west and north-west - south-east direction (Sukardi and Budhisutrisna, 1992).

Geomorphology of Bandung area can be divided into 2 geomorphologic unit, they are flat - gently undulating river terrace unit and gently - steep hillocky unit. This area con- sist of 5 lithology unit, from older to younger are calcareous claystone unit, montmorillonitic claystone-sandstone-1 unit, montmorillonitic claystone unit, montmorillonitic claystonesandstone-2 unit that unconformably overlaid by clay - gravel unit (Figure 11. Montmorillonitic claystone is belongs to Kerek Formation that have middle Miocene age and had been deposited in marine environment (inner - middle neritic zone) by turbidity current mechanism, whereas clay - gravel unit is in quartenary age river deposit. Folds associate with reverse fault are the dominant geology structures in this area. The fold is often plunged and has eastwest orientation. Similar with the folds, reverse fault found associated with fold also in the same orientation. These geology structures are formed by relatively north-south compression.

\section{Methodology}

Montmorilonitic claystone samples from Bandung area were analysed in term of mineralogy and physical properties (cation exchange capacity/CEC and swelling ability). Mineralogical characterization were conducted by petrographycal observation, X-ray diffraction (XRD) measurement and scanning electron microscope (SEM/EDX) observation. Petrographical observations and XRD measurement were done in Geological Engineering Department, Gadjah Mada University, whereas SEM was observed in Quartenary Geology Laboratory, Geological Survey Center, Bandung. CEC measurement was done in Ceramic Laboratory, Chemical Engineering, Gadjah Mada University and swelling ability measurement was done in Geological Engineering Department, Gadjah Mada University.

\section{Results}

\section{Mineralogy}

Montmorillonitic claystone megascopically is characterized by white - brownish grey color, clastic texture, fine sand - clay grain-sized, predominatly composed of clay minerals, quartz, calcite and feldspar. It has plastic property when mixed with a limited amount of water, 


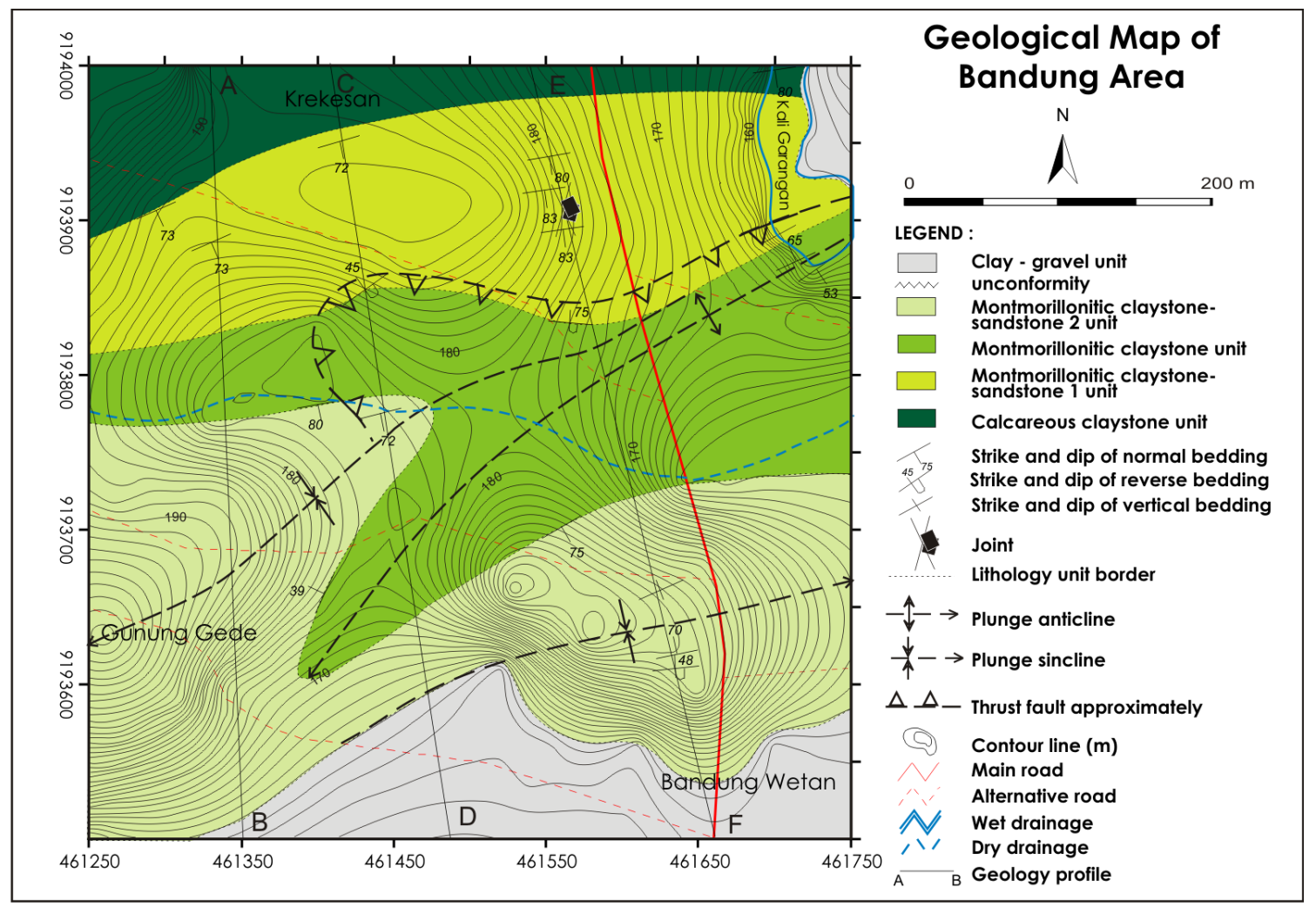

Figure 1: Geological map of Bandung area

often forms yellowish slippery jelly deposit after rain and shows mud crack structure when it dries.

The petrographycal observation result indicates that montmorillonitic claystone is characterized by a number of volcanic glass that altered to secondary minerals $(30-40 \%)$, calcite $(10-25 \%)$, volcanic glass $(15-20 \%)$, ortoclase $(0-10 \%)$, quartz $(5-20)$, plagioclase $(0-15 \%)$, opaq minerals $(5-15 \%)$ and lithic $(0-5 \%)$ (Figure 2).

XRD result shows peaks that indicates Ca-montmorillonite, kaolinite, illite, zeolite (heulandite, mordenite), quartz, plagioclase, potassium feldspar (ortoclase and sanidine), calcite and magnetite. Ca-montmorillonite has relatively higher intensity than other clay minerals content (Figure 3).

SEM analyses results dominanly shows webby structure of montmorillonit, pseudohexagonal structure of kaolinite, hairy structure of illite, mordenite appear as elongate rod shape, potassium feldspar and plagioclase in tabular shape, and calcite that appear as crys- talline calcite, coccolith plates or foraminiferal test (Figure 4).

\section{Physical Properties}

Physical properties of montmorillonitic claystone are represented by Cation Exchange Capacity (CEC) and swelling ability.

Initial CEC of montmorillonitic claystone is about 20,0 mgrek. $\mathrm{Na}_{2} \mathrm{O} / 100 \mathrm{gr}$. It is increasing with the thermal activation given at three variable tempeture $200{ }^{\circ} \mathrm{C}, 250{ }^{\circ} \mathrm{C}$ and $300^{\circ} \mathrm{C}$ for 1 hour duration of each activation temperature. After these activation, CEC values are increasing respectively 26,0 mgrek. $\mathrm{Na}_{2} \mathrm{O} / 100 \mathrm{gr}$, 26,8 mgrek. $\mathrm{Na}_{2} \mathrm{O} / 100 \mathrm{gr}$ and 28,0 mgrek. $\mathrm{Na}_{2} \mathrm{O} / 100 \mathrm{gr}$. As seen on the graph, activation temperature has positive corelation with the CEC values. (Figure 4, 5).

Swelling ability of montmorillonitic claystone is measured using a simple method: the rocks samples are crushed and sieve. As the result is rock powder in $-100+200$ mesh grain sized. The powder is taken for $2 \mathrm{ml}$ (initial 

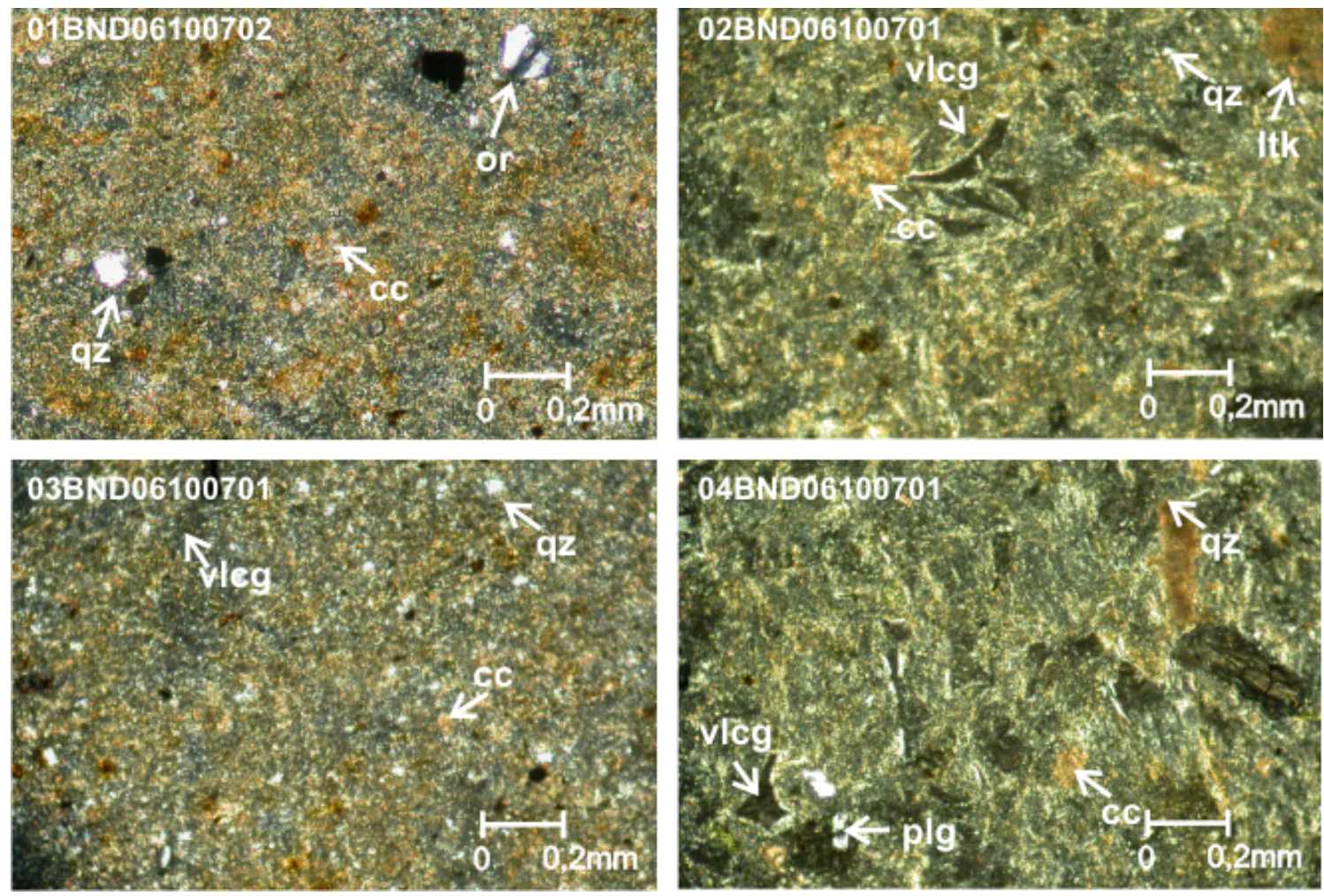

Figure 2: Photomicrographs of montmorilonitic claystone thin sections, showing that a part of volcanic glass(vlcg) has altered to secondary minerals

volume) and put into a $10 \mathrm{ml}$ size of measure glass. Than $8 \mathrm{ml}$ of aquadest is poured into this glass to soak the rock powder. The powder will sweel and the volume is noted per hour until it is stop swelling. For this measurement, the powder is stop swelling after 6 hours. The powder volume after $6^{\text {th }}$ hour is measured as final swelling volume. This result then compared with initial volume as swelling percentage ability. The result shows that the swelling ability of montmorillonitic claystone varies from $50 \%$ to $100 \%(65 \%$ in average, see Figure 6$)$.

\section{Bentonite Genesis and Discussion}

The genesis of clay minerals can be studied based on their mechanisms (heritage, transformation and neoformation) and environment (weathering, sedimentation, diagenesis, hydrothermal) (Grim, 1968; Lucas, 1968; Millot, 1970; Velde, 1995). Genesis of bentonite is related to pyroclastic rocks and derived from insitu alteration of ash and pyroclastic tuff by hydration in shallow lacustrine or marine environment. Geological process that cause alteration in volcanic materials is assured by either hydrothermal or diagenetic (Yildiz and Kuscu, 2004).

Intermediate type of bentonite ( $\mathrm{Na}$ or $\mathrm{Na}-\mathrm{Ca}$ ) is generally formed by diagenetic process (Grim and Güven, 1978 dalam Takagi et al., 2005). Ca-bentonite type mostly occurred as irregular or lenticular shape small to medium scale ore body. Bentonit of this type tend to be formed, not only by diagenesis but also by hydrothermal or deuteric alteration (Takagi et al., 2005). Bentonite deposit that is formed by diagenetic process usually has stratiform shape, whereas bentonite that is formed by hydrothermal alteration usually has funnel shape, associate with intrusion body, altered wall rocks and a gradation in quality toward the intrusion body (Takagi et al., 2005).

Genesis of montmorillonitic claystone is interpreted from field data, laboratory data and supported with secondary data from previous author. Montmorillonitic claystone of Bandung area found associate with sandstone and silt- 

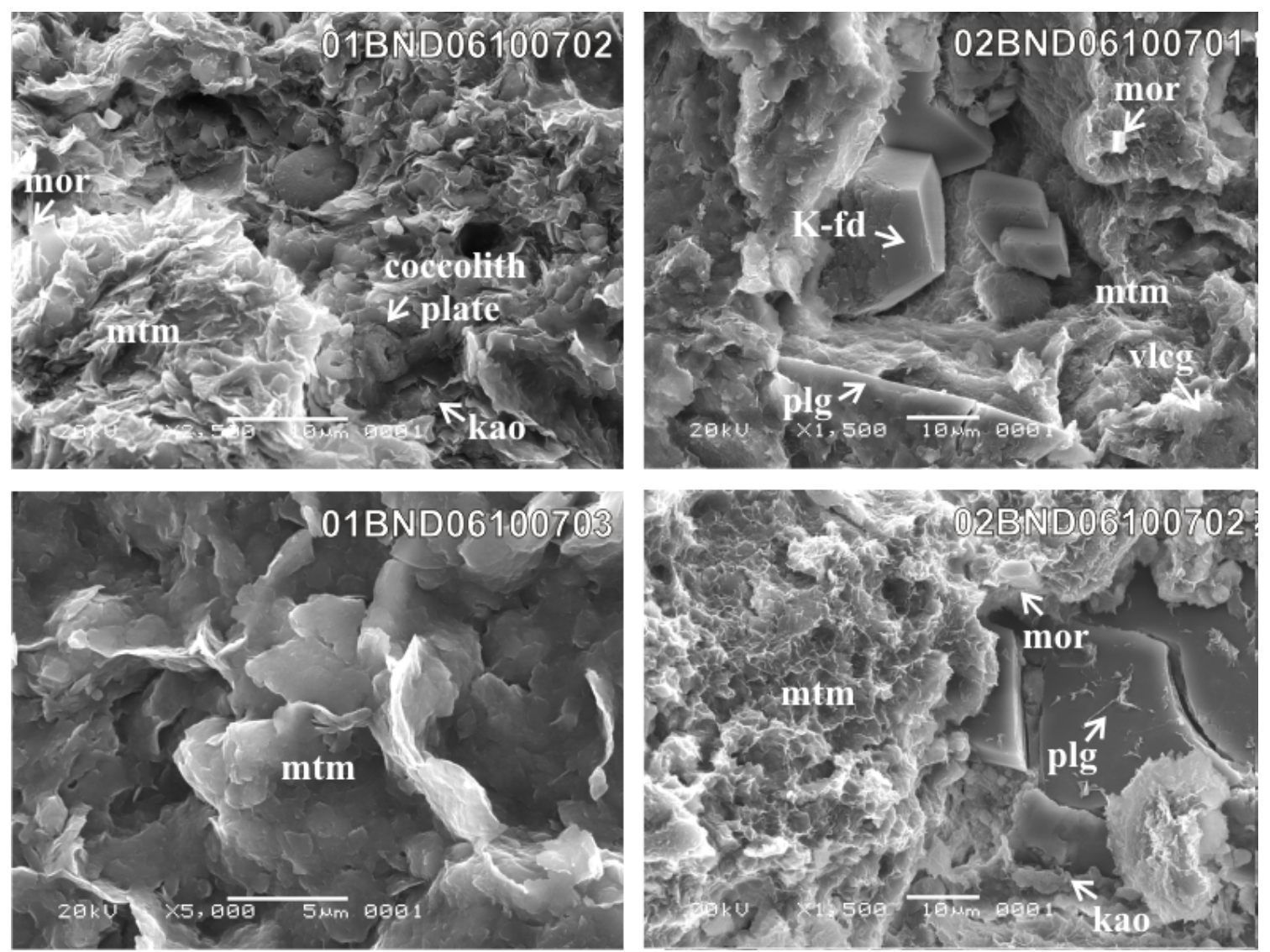

Figure 4: Scanning electron microscope (SEM) images of montmorilonitic claystone 


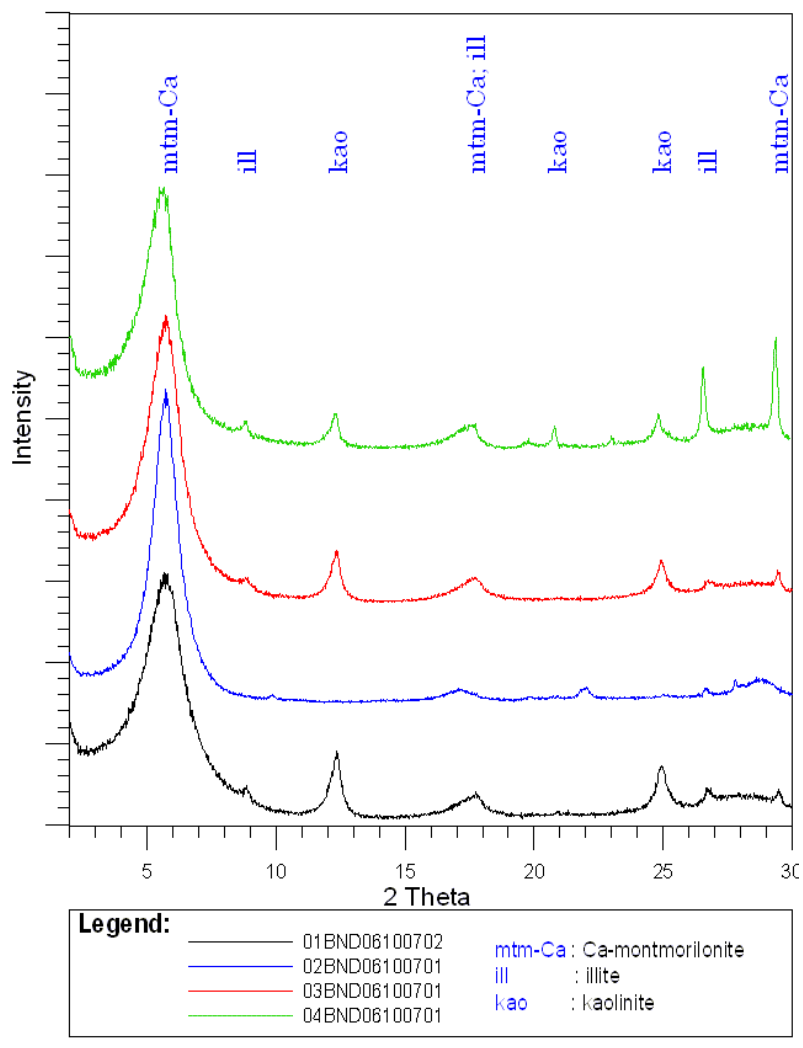

Figure 3: The X-Ray Diffraction (XRD) pattern of montmorilonitic claystone in clay minerals analysis

stone. These rocks are volcanic clastic deposit that very abundant in volcanic tuff content, especially volcanic glass. This material can be altered easily in diagenetic environment (Velde, 1995). This rocks is N13 - N14 in age and belongs to Kerek Formation from Banyuurip Member. Based on field data and geology profile, montmorillonitic claystone has coverage in gently - steep hillocky morphology unit. It has stratiform shape which tend to be found in diagenetic deposit result (Takagi et al., 2005).

From thin sections, can be observed that volcanic glass partially altered to secondary minerals, probably as clay minerals and or zeolite. It is identified from the shard structure of volcanic glass. SEM result shows clay minerals growth in the intergranular space and in the silicate minerals surface. It indicate that clay minerals are the result of neoformation (ionic precipitation from the solution) in devitrivication process (Lucas, 1968). This process could happen because of temperature changes dur-

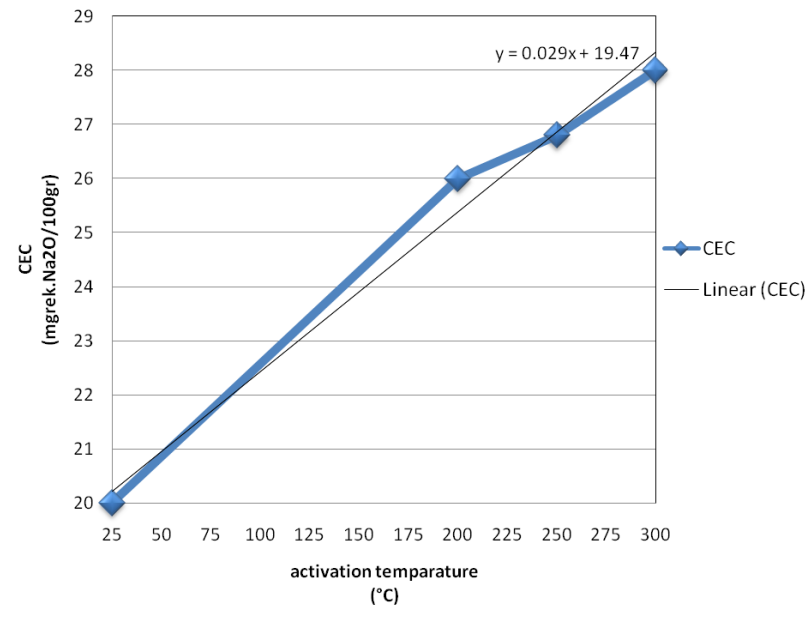

Figure 5: Relation between activation temperature and CEC value of montmorilonitic claystone

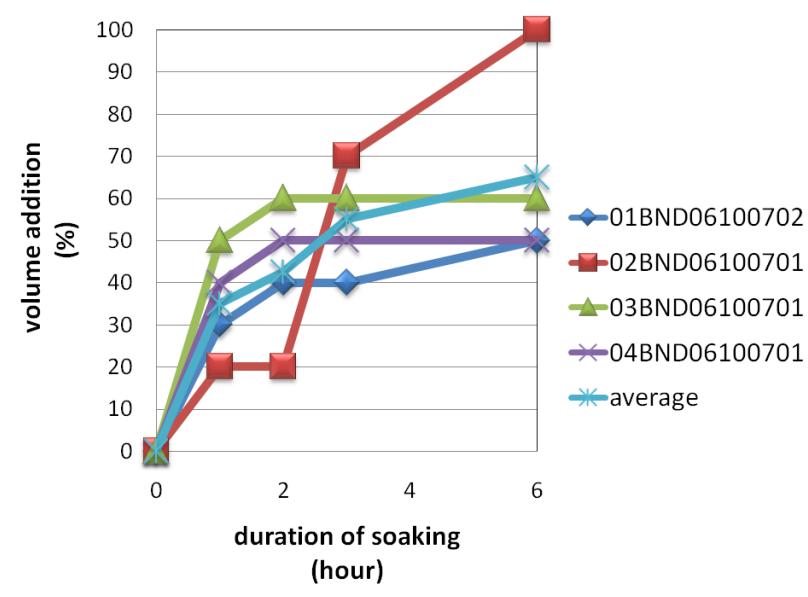

Figure 6: Relation between time of soaking and volume addition of montmorilonitic claystone in swelling ability measurement

ing diagenesis by sediment overburden (burial diagenesis). XRD identification result shows association of some silicate minerals: mordenite, heulandite, montmorillonite and illite. This association indicate zone IIIa of silicate minerals zonation during diagenesis (Ijima, 1978 vide Fisher and Schmincke, 1984). Montmorillonite relatively stable in the early stage of zone IIIa. Illite is probably formed as the alteration result of smectite group minerals during burial diagenesis (Potter et al., 2005).

Secondary regional geology data revealed that Kerek Formation is covered by $\pm 2 \mathrm{~km}$ thick of overburden. Based on Ijima (1978, vide 
Fisher and Schmincke, 1984), on his study with thick volcanic clastic sediment in Japan, the border of zone II/IIIa in this sediment is 1700 $3500 \mathrm{~m}$ in depth and $84-91^{\circ} \mathrm{C}$ in temperature. This is suitable with regional data of sediment overburden in study area. From the explanation above, assured that clay minerals in montmorillonitic claystone are formed in the situation of burial diagenesis with $\pm 2 \mathrm{~km}$ thick of overburden. This interpretation is made with assumption that Bandung area has similar geothermal gradient with previous study area in Japan.

\section{Conclusions}

Bentonite is potentially found in montmorillonitic claystone-sandstone-1 unit, montmorillonitic claystone unit and montmorillonitic claystone-sandstone-2 unit. This rocks belongs to Kerek Formation, Middle Miocene in age and deposited in marine environment (inner - middle neritic zone) by turbidity current mechanism. Montmorillonitic claystone is characterized by white - brownish grey color, clastic texture, fine sand - clay grain-sized, predominatly composed of Ca-montmorillonite. This rocks also contain kaolinite, illite, zeolite (heulandite, mordenite), quartz, plagioclase, potassium feldspar (ortoclase and sanidine), calcite (crystalline calcite, coccolith plates or foraminiferal test) and magnetite. Initial CEC of montmorillonitic claystone is about 20,0 mgrek. $\mathrm{Na}_{2} \mathrm{O} / 100 \mathrm{gr}$ and the swelling ability is relatively low varying from $50 \%$ to $100 \%$ (65\% in average). This deposit is included to Ca-Bentonite type and has stratiform shape. The genesis of this deposit is probably from devitrivication of volcanic glass in diagenetic environment with $>2 \mathrm{~km}$ thick of overburden.

\section{Acknowledgements}

This study has been carried out as a collaborative research under Earth Resources and Geological Engineering, Asian University Network/SEED-Net project supported by Japan International Corporation Agency (JICA). The authors are also very thankful to the Government of Boyolali Residency, which has given permission to do investigation at Bandung deposit.

\section{References style}

Arifin, M. and Sudrajat, A. (1997) Bentonit, Bahan Galian Industri, Suhala, S., and Arifin, M. (editor), Mineral Technology Research and Development Center, Bandung.

Bemmelen, R.W. van (1949) The Geology of Indonesia: General Geology of Indonesia and Adjacent Archipelagoes, 2nd ed., Vol. 1A, Martinus Nijhoff the Haque.

Fisher, R.V. and Schmincke, H.U. (1984) Pyroclastic Rocks, Springer-Verlag, Berlin

Grim, R.E. (1968) Clay Mineralogy, $2^{\text {nd }}$ edition, McGraw-Hill Book Company, New York.

Lucas, J. (1968) The Transformation of Clay Minerals During Sedimentation a Study on Triassic Clay, Israel Program for Scientific Translation Ltd., Jerusalem.

Millot, G. (1970) Geology of Clays, Masson Et C, Paris, Hapman \& Hall, London.

Potter, E.E., Maynard, J.B., and Depetris, P.J. (2005) Mud and Mudstone, Springer, Berlin.

Sukardi and Budhisutrisna,T. (1992) Peta Geologi Bersistem Indonesia: Lembar Salatiga 1408-6, Geology Research and Development Center, Bandung

Suwasti (2005) Geologi Daerah Wonosegoro and Sekitarnya, Kecamatan Wonosegoro, Kabupaten Boyolali, Jawa Tengah, Field Mapping Report, Geological Engineering Dept., Faculty of Engineering, Gadjah Mada University, Yogyakarta, unpublished

Takagi, T., Koh, S.M., Song, M.S., Itoh, M. and Mogi, K. (2005) Geologi and Properties of the Kawasaki and Dobuyama Bentonite Deposite of Zao Region in Northeastern Japan, Clay Minerals 40, The Mineralogical Society, p. $333-350$

Titisari, A.D., and Widiasmoro (2006) Mineralogical Characteristics of the Kedungbedah Bentonite, Boyolali, Indonesia, Proceedings of The 8th Field Wise Seminar on Geological Engineering Field and The 3rd International Symposium \& Exhibition on Earth Resources and Geological Engineering Education, Gadjah Mada University, Yogyakarta, p. $309-315$

Utama, A.P. (2004) Genesa Bentonit di Kecamatan Wonosegoro Kabupaten Boyolali Propinsi Jawa Tengah and Aplikasinya Sebagai Bahan Baku Keramik, Thesis, Geological Engineering Dept., Faculty of Engineering, Gadjah Mada University, Yogyakarta, unpublished 
Velde, B. (1995) Origin and Mineralogy of Clays, Clays and the Environment, Springer, Berlin

Yildiz, A. and Kuscu, M. (2004) Origin of the Basoren (Kutahya, W Turkey) Bentonite Deposite,
Clay minerals 39, The Mineralogical Society, p. $219-231$ 